\title{
New species, lectotypes and synonyms of Australasian Nymphaea (Nymphaeaceae)
}

\author{
S.W.L. Jacobs
}

\begin{abstract}
Jacobs, S.W.L. (National Herbarium of New South Wales, Royal Botanic Gardens, Sydney, NSW, Australia 2000) 1991. New species, lectotypes and synonyms of Australasian Nymphaea (Nymphaeaceae). Telopea 4(4): 635-641. As a precursor to the forthcoming treatment of Nymphaeaceae for the 'Flora of Australia', Nymphaea elleniae, N. atrans, N. immutabilis and N. immutabilis subsp. kimberleyensis are described as new taxa; lectotypes are chosen for $N$. violacea and some of its synonyms, namely $N$. violacea var. caerulea, $N$. holtzei, $N$. rehneltiana and $N$. casparyi; $N$. dictyophlebia is placed as a synonym under $N$. macrosperma; and some other names are discussed.
\end{abstract}

\section{Introduction}

The following descriptions, lectotypifications, and discussion are provided as precursors to the treatment of Nymphaeaceae for the 'Flora of Australia'. Only those aspects necessary for that treatment are discussed here; it is planned to produce a fuller account on other aspects soon. This fuller account will include scanning electron micrographs of the seeds of at least all the native species.

\section{New species}

Nymphaea elleniae S.W.L. Jacobs, sp. nov.

$N$. violaceae affinis sed filamentis antherarum brevioribus, sepalis brevioribus, floribus semper candidis, floribus foliisque plerumque minoribus, differt.

TYPE: QuEENSLAND: Jardine River, $11^{\circ} 09^{\prime}$ S $142^{\circ} 20^{\prime} \mathrm{E}$, S. Jacobs 5450 \& J. Clarkson, 6 Aug 1987 (holo NSW; iso BRI).

Perennial with vertical elongated rhizome. Juvenile submerged leaf blades often retained for several years, sagittate, usually red; mature blade to $22 \mathrm{~cm}$ long, $18 \mathrm{~cm}$ wide, undersurface often red, especially toward the margin, margins entire to slightly sinuate. Flowers to $20 \mathrm{~cm}$ above the water surface. Sepals 4, to $7 \mathrm{~cm}$ long, green outside with purple flecks; margins membranous, white; tip acute or occasionally obtuse. Petals to 25, grading into the stamens, lanceolate, white; tip acute to obtuse. Stamens to c. 100; filaments membranous, to $18 \mathrm{~mm}$ long; anthers to $8.5 \mathrm{~mm}$ long, sometimes slightly apiculate. Ovary lobed; carpels 11-22; fruit globose, c. $2.5 \mathrm{~cm}$ diam., with numerous seeds; seeds elliptical, c. 1.75-2.5 mm long, c. 1-1.5 mm diam., glabrous; cells of the testa having a small lumen, occasionally raised relative to the arms, with arms of unequal length, ends neither expanded nor raised. 
On Cape York in and north of the Jardine River, Queensland; also in New Guinea. Growing in more or less permanent water to $5 \mathrm{~m}$ deep, flowering ?April toDecember. Flowers open all day, closing at night.

This species is very similar to $N$. hastifolia Domin but, unlike that species, $N$. elleniae grows in more permanent water and usually does not start flowering until after $N$. hastifolia has finished. There is also a difference in the seeds: the cells of the testa appear to have a 'double wall' in $N$. hastifolia with the appearance of an extra line in scanning electron micrographs of the seed.

$N$. elleniae differs from $N$. violacea in always being white-flowered, having shorter filaments, and the flowers and leaves being generally smaller; $N$. elleniae also often retains its juvenile leaves for much longer.

Named after my daughter, Ellen A. Jacobs.

Qufensland: Burster Ck, 10 55' S 142 22' E, Clarkson 6185, Aug 1985 (BRI, NSW); c. 20 km W of Karwah Lagoon, $13^{\circ} 44^{\prime} \mathrm{S} 141^{\circ} 54^{\prime} \mathrm{E}$, Clarkson 4568, Oct 1982 (BRI); Skull Ck, $10^{\circ} 55^{\prime} \mathrm{S} 142^{\circ}$ 22' E, Jacobs 5458 \& Clarkson, Aug 1987 (NSW). PAPua New Guinea: Western Province: Pongarihi, c. $30 \mathrm{~km}$ E of Morehead, road to Arufi, 8 40' S, 141 ${ }^{\circ} 50^{\prime}$ E, Jacobs 5959 \& Conn, Sept 1990 (NSW, LAE, UPNG); Seki village, N of Morehead 8 21' S 141 $54^{\circ}$ E, Jacobs 5978 \& Conn, Sept 1990 (NSW, LAE, UPNG).

\section{Nymphaea atrans S.W.L. Jacobs, sp. nov.}

$N$. giganteae affinis sed floribus fructibusque ad maturitatem vinosis, basi vaginanti petioli latiora, differt.

Type: QueEnsland: c. $10 \mathrm{~km} \mathrm{~N}$ of Wakooka, Bathurst Bay road, c. $14^{\circ} 28^{\prime} \mathrm{S} 144^{\circ} 33^{\prime} \mathrm{E}$, S. Jacobs 5398 \& J. Clarkson, 31 July 1987 (holo NSW; iso BRI).

Perennial with a short vertical swollen rhizome. Petiole base winged; mature leaf blade to $\mathrm{c}$. $40 \mathrm{~cm}$ diam.; margins toothed with few regularly-spaced teeth to $2 \mathrm{~mm}$ long. Flowers to $40 \mathrm{~cm}$ above the water surface. Sepais 4 , to $8 \mathrm{~cm}$ long, green outside with purple streaks, darkening to maroon with age; the margins membranous, light pink when young and progressively darkening to maroon with age; tip obtuse. Petals to 33 , with a gap between petals and stamens, oblanceolate, white with pink tinge, becoming darker with age; tip obtuse. Stamens to c. 300, filaments membranous to cylindrical, to $14 \mathrm{~mm}$ long; anthers to $10 \mathrm{~mm}$ long, usually with a small hooked apical appendage. Ovary lobed; carpels 10 to 15; fruit globose, c. $4 \mathrm{~cm}$ diam., with numerous seeds; seeds elliptical, c. $4 \mathrm{~mm}$ long, c. $2.5 \mathrm{~mm}$ diam. with discontinuous or disorganised rows of very short hairs; cells of the testa having an elongated lumen with arms of equal length, the ends usually expanded but not raised.

Cape York, Queensland, in Lakefield National Park and its vicinity. Billabongs, lakes and old pastoral dams on floodplains. Flowering ?July to November; flowers open during the morning (and at night?).

Similar to other species in the 'gigantea' group but differing in the apparent nightflowering, the more developed sheathing base of the petiole, and the petals and sepals darkening with age. The sepals, as well as the fruit, become almost deep maroon as the fruit is drawn beneath the surface. The hairs on the seed are shorter than those on other species in this group. $N$. atrans hybridises with $N$. immutabilis and the hybrids are obvious from the pink older flowers, the flowers of the hybrid never becoming as dark as those of $N$. atrans. The hybrids, unlike both parent species, do not have a good seed-set.

Named from the Latin atrans, meaning darkening, referring to the flower darkening with maturity. 
QueEnSLAND: Romeo Lagoon, Lakefield National Park, $15^{\circ} 09^{\prime} \mathrm{S} 144^{\circ} 15^{\prime} \mathrm{E}$, Jacobs 5414 \& Clark-

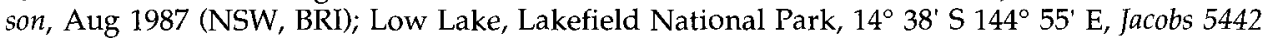
\& Clarkson, Aug 1987 (NSW, BRI); 'Bizant', Lakefield National Park, 14 $41^{\prime}$ S $144^{\circ} 12^{\prime}$ E, Williams 85259, Oct 1985 (BRI).

\section{Nymphaea immutabilis S.W.L. Jacobs, sp. nov.}

N. giganteae affinis sed antheris longioribus, petalis ad maturitatem nonpallescentibus, ciliis seminum seriatum dispositis sed minus ordinatis, differt.

Type: QueEnSLAND: c. $1 \mathrm{~km}$ SW of Emerald Ck, nr Mareeba, $17^{\circ} 01^{\prime} \mathrm{S} 145^{\circ} 30^{\prime} \mathrm{E}, \mathrm{S}$. Jacobs 5338 \& J. Clarkson, 26 July 1987 (holo NSW; iso BRI).

Annual or perennial with vertical globular rhizome. Mature leaf blade to c. $70 \mathrm{~cm}$ diam.; margins toothed with regularly-spaced teeth to $4.5 \mathrm{~mm}$ long. Flowers to $50 \mathrm{~cm}$ above the water surface. Sepals 4, to $12.5 \mathrm{~cm}$ long, green on the outside with purple flecks; margins membranous and coloured as the outer petals; tip obtuse. Petals to 34, with a gap between petals and stamens, oblanceolate to spathulate, white, sometimes with a blue tinge, or blue, usually not fading with age; tip obtuse. Stamens to c. 400; filaments membranous to cylindrical, to $32 \mathrm{~mm}$ long; anthers to $15 \mathrm{~mm}$ long, often apiculate. Ovary lobed; carpels 9 to 20 ; fruit globose, c. $5 \mathrm{~cm}$ diam., with numerous seeds; seeds elliptical, c. $4 \mathrm{~mm}$ long, c. $2.5 \mathrm{~mm}$ diam., with discontinuous or disorganised rows of short, sparse to dense, sometimes almost scattered, hairs, rarely glabrous; cells of the testa having an elongated lumen with arms of equal to unequal length, ends sometimes slightly expanded but not raised.

Widespread in the monsoonal parts of the Australian tropics from the Kimberley, Western Australia to about the Tropic of Capricorn in coastal Queensland. In permanent or ephemeral waterholes. Flowering March to November; flowers open during the day and close at night.

At various times this species has been included in $N$. gigantea or incorrectly known as $N$. dictyophlebia (a synonym of $N$. macrosperma, see below). The distributions of $N$. gigantea and N. immutabilis overlap around Rockhampton on the Queensland coast and specimens from this area can be difficult to identify unless collected with seeds, information on flower colour, and whether there is any sign of petal colour fading with maturity. There is presumably some intergradation between the two species in this area.

From the Latin immutabilis, not changing, referring to the petals, which usually do not change colour with maturity in this species, unlike $N$. gigantea where those flowers that are originally coloured usually fade, or N. atrans where they darken.

There are two subspecies.

1 Petals mostly white, outer whorls often tinged blue, or the petals all white or all blue, not fading with age; sepals to $10.5 \mathrm{~cm}$ long; stamens to c. 400 ; anthers without a gland at the base; leaf blade margin with teeth to $4.5 \mathrm{~mm}$ long; carpels 9-19; seeds pubescent subsp. immutabilis

$1^{*}$ Petals blue with white at base, fading slightly with age; sepals to $12.5 \mathrm{~cm}$ long; stamens to c. 200; anthers with purple gland at base; blade margin with teeth to $3 \mathrm{~mm}$ long; carpels 15-20; seeds apparently glabrous subsp. kimberleyensis 
Nymphaea immutabilis S.W.L. Jacobs subsp. immutabilis

$N$. lotus var. australis Bailey (1899: 38)

LECTOTYPE (here designated): QueEnSLAND: Kamerunga, Barron R., E. Cowley 7, Aug 1891 (BRI).

In the work cited above, Bailey refers the publication of his variety to an earlier work (Bailey 1883); however, while the 1883 publication mentions a variety it offers neither name nor specimen. The name first appears in Bailey (1899) with a somewhat vague specimen citation 'Hab.: Still waters off the Barron River.' The specimen at BRI is clearly labelled by Bailey.

Rhizome swollen and vertical, usually less than $8 \mathrm{~cm}$ long. Mature leaf blade with teeth to $4.5 \mathrm{~mm}$ long on margin. Sepals to $10.5 \mathrm{~cm}$ long. Petals white, with outer whorls often tinged blue, less commonly the petals all white or all blue, not fading with age. Stamens to c. 400 ; filaments to $28 \mathrm{~mm}$ long; anthers to $15 \mathrm{~mm}$ long, without a gland at the base. Carpels 9 to 19; fruit globose, c. $5 \mathrm{~cm}$ diam.; seeds with discontinuous or disorganised rows of short hairs that sometimes almost appear scattered.

Distribution, habitat, flowering months and flowering times as given for the species.

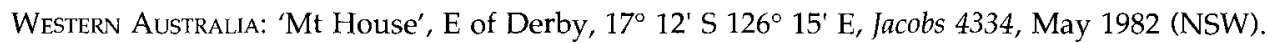
Northern Territory: 'Singleton' Station, 20 48' S 134 16' E, Henshall 1047, June 1975 (MEL). QuEENSLAND: Normanton to Karumba road between Normanton and Maggieville, $17^{\circ} 03^{\prime} \mathrm{S} 141^{\circ}$ 00' E, Clarkson 2697, Nov 1979 (BRI); 'Westmoreland' homestead lagoon, $17^{\circ} 16^{\prime} \mathrm{S} 138^{\circ} 15^{\prime} \mathrm{E}$, Jacobs 1551, May 1974 (NSW); Camooweal, 19³ 35' S 138 07' E, Jacobs 5531 \& P. Wilson, May 1988 (NSW).

Nymphaea immutabilis subsp. kimberleyensis S.W.L. Jacobs, subsp. nov.

Subsp. immutabili affinis sed petalis plerumque ad imum candidis apicem versus violaceis, sepalis longioribus, staminibus paucioribus, differt.

Type: Western Australia: Kimberley region, S. Jacobs 5706 \& P. Wilson 23 May 1988 (holo NSW; iso PERTH).

Rhizome swollen and vertical, to $12 \mathrm{~cm}$ long. Mature leaf blade with teeth to $3 \mathrm{~mm}$ long on margin. Sepals to $12.5 \mathrm{~cm}$ long. Petals blue with white at base, fading slightly with age. Stamens to c. 200; filaments to $32 \mathrm{~mm}$ long; anthers to $13 \mathrm{~mm}$ long, with a purple gland at the base of the anther. Carpels 15 to 20; only immature seeds seen, apparently glabrous.

Known from only one population in the Kimberley, from a lagoon that dries out each year. Flowers open during the day and presumably close at night; flowering from ?March to June. Because of the apparent rarity of this subspecies I have not published precise locality information although this information has been passed on to relevant Government conservation authorities.

Western Australia: Kimberley region, Jacobs 5707 \& P. Wilson, 23 May 1988 (NSW). 


\section{Nymphaea violacea and synonyms}

Nymphaea violacea Lehm. (1853: 218).

N. gigantea var. violacea (Lehm.) Conard (1905: 130-131)

LECTOTYPE (here designated): QueENSLAND: Cape York, Macgillivray Voyage of Rattlesnake, Bot. 410, 10 October $1848(\mathrm{~K})$.

N. violacea var. caerulea Lehm. (1853: 218), as 'coerulea'.

LectotyPe (here designated): QueEnsLAND: Cape York, Macgillivray Voyage of the Rattlesnake, Bot. 410 ß, 27 October 1849 (lecto K; isolecto B).

Lehmann (1853) described two varieties of $N$. violacea, the type variety as $\alpha$ and var. caerulea as $\beta$. He cited only one specimen from Macgillivray as the type for $\beta$ and two specimens for $\alpha$, one collected by Macgillivray and one by Anderson. I have been unable to find any specimens collected by Anderson but found both specimens from Macgillivray clearly labelled at K and a duplicate of one of these at B. Lehmann's herbarium was dispersed after his death, the Nymphaeaceae being purchased by Caspary (Nordenstam 1980). Caspary's herbarium was mostly deposited at B where many specimens were destroyed during World War II, but there are some duplicates at K (Stafleu \& Cowan 1976). A search at B revealed a Macgillivray specimen of $\beta$ that had been damaged by insects, and a substantial collection of Caspary's 'hybrids'. The hybrids were derived from artificially pollinated specimens of what, at that time, were regarded as separate species; nearly all of the parents are now treated by Verdcourt (1989) as synonyms of $N$. nouchali Burm. f. The label of the Macgillivray specimen at $B$ has been altered in an attempt to change the collection date from that for $\beta$ to that of $\alpha$, presumably in ignorance of there having been two specimens from the same 'locality' at different dates. Royen (1962) cites the Anderson collection as being in HBG. A search there failed to locate any Australian Nymphaea specimens, although there are Anderson collections in other families; there seems no evidence of Caspary's herbarium in HBG. The two specimens at $\mathrm{K}$ are in good condition, have the advantage of being in the same herbarium, have been seen and annotated by Lehmann, do not seem to have had their labels altered, and match their relevant descriptions. I am therefore choosing these specimens as lectotypes for Lehmann's two varieties of $N$. violacea.

\section{N. holtzei Rehnelt \& Henkel ex Henkel, Rehnelt \& Dittman (1907: 67).}

Type citation: 'Gesammelt von Direktor M. Holtze auf den Melville-Inselen, 40 engl. Meilen von Port Darwin'.

LECTOTYPE (here designated): Lefthand figure accompanying the description (Henkel et al. 1907: 67).

I have been unable to find a Holtze specimen labelled with these details. If one existed it was possibly destroyed in B. There are two unnumbered figures accompanying the description. The unnumbered figure on the left is clearly $N$. violacea. $N$. stellata F. Muell. (non Willd.) is a nomen nudum cited as a synonym of $N$. holtzei in the protologue, and Mueller used his name for what is now recognized as $N$. violacea. The description of $N$. holtzei is a good match for $N$. violacea. I here designate the lefthand 
figure accompanying the description on p. 67 as the lectotype. The unnumbered figure on the right is of the tubers and could belong to a young plant of nearly any Australian species.

N. holtzei var. albiflora Rehnelt \& Henkel ex Henkel, Rehnelt \& Dittman (1907: 67).

TYPE CITATION: 'Eleonorae hort.'

The distinguishing feature of this variety, 'Floribus niveis' is added after the diagnostic description of the species. Flower colour alone is an unreliable character for distinguishing species of Nymphaea; this variety albiflora presumably consists of common white-flowered plants of $N$. violacea. There is no indication of any specimen or drawing that could be used in lectotypification.

N. rehneltiana Henkel (1910: 154-156).

LECTOTYPE (here designated): Fig. 11 on p. 155 of the protologue.

There is no indication in the original description of a specimen existing other than the statement that the species was cultivated at the Botanic Garden in Giessen. The description matches $N$. violacea and there is an awkward but perfectly adequate and diagnostic drawing in the protologue that I now select as the lectotype.

N. casparyi Rehnelt \& Henkel ex Henkel, Rehnelt \& Dittman (1907: 66) nom. illeg.; non $N$. casparyi Carrière (1879).

Type citation: 'Im Herbar Kew liegen Blätter von ihr, gesammelt von Ferd. v. Müller, bezeichnet als versicolor, repanda und serrata. Eines derselben ist mit Banksii Cunn. bezeichnet.'

LectotyPe (here designated): 'N. repanda', Head of Sturts Creek, F. Mueller (K).

Although it is not necessary to lectotypify illegitimate names there is some value in doing so for this case. Rehnelt and Henkel's name has been used in the literature, sometimes cited as a nom. illeg., and the unnumbered drawing with the protologue has also been referred to. The problem springs from their name being based on collections of two different species. There are four specimens listed by Rehnelt and Henkel, all from $\mathrm{K}$; three of the specimens have been labelled by Mueller as either 'versicolor', 'repanda' or 'serrata' and one labelled as 'banksii' by Allan Cunningham. All the names are nomina nuda; the specimens labelled versicolor, repanda, and banksii are all $N$. violacea and the specimen labelled serrata belongs to a species near $N$. gigantea Hook., possibly N. macrosperma. The figure with the type description is a composite of the two species, as is the description. In order to reduce confusion I have selected as lectotype the specimen designated above.

\section{New synonym}

Nymphaea macrosperma Merrill \& Perry (1942: 389).

Type: Papua New Guinea: Lake Daviumbu, Middle Fly River, L. Brass 7608, Aug 1936 (holo $\mathrm{A}$; iso $\mathrm{BM}, \mathrm{BRI}$ ). 
N. dictyophlebia Merrill \& Perry (1942: 390), syn. nov.

Type: Papua New Guinea: Penzara, between Morehead and Wassi Kussa Rivers, L. Brass 8437, Dec 1936 (holo A; iso BM, BRI).

The names Nymphaea macrosperma and Nymphaea dictyophlebia were both published in the same paper but are referable to the same species. Understandably there has been some confusion in the application of these names although $N$. macrosperma has been used correctly more frequently than $N$. dictyophlebia, the latter name sometimes being used for the species described here as $N$. immutabilis. To minimise changes to current usage I have selected $N$. macrosperma as the name for this taxon.

\section{Acknowledgments}

Many thanks to Geoff Sainty, John Clarkson and Ian Cowie who, among others, were effective crocodile decoys and collectors of valuable specimens. Thanks also to Carolyn Porter and Sue Chambers for invaluable technical assistance, Joy Everett, Roger Carolin and Helen Aston for their comments on the manuscript, Terry Macfarlane and Greg Leach for help while Australian Botanical Liaison Officers, Karen Wilson for the Latin diagnoses and help while Liaison Officer, and to The Royal Geographical Society and The Linnean Society of London for supporting my participation in the Kimberley Research Project, 1988.

\section{References}

Bailey, F.M. (1883) A synopsis of the Queensland flora. (Government Printer: Brisbane).

Bailey, F.M. (1899) The Queensland Flora, part 1. (H.J. Diddams \& Co.: Brisbane).

Carrière, E.A. (1879) Nymphaea caspary. Revue Horticole: 230 (not seen, quoted in Conard 1905). Conard, H.S. (1905) The waterlilies. (Carnegie Institute: Washington).

Henkel, von F., Rehnelt, F. \& Dittman, L. (1907) Das Buch der Nymphaeaceen oder Seerosengewäschse (Darmstadt).

Henkel, von F. (1910) Nymphaea Rehneltiana Henkel, species nova. Gartenflora, Zeitschrift fur Gartenund Blumenkunde 59: 154-156.

Lehmann, C. (1853) Ueber die Gattung Nymphaea. Hamburger Garten- und Blumenzeitung 9: 193218.

Merrill, E.D. \& Perry, L.M. (1942) Plantae Papuanae Archboldianae X. Journal of the Arnold Arboretum 23: 383-416.

Nordenstam, B. (1980) The herbaria of Lehmann and Sonder in Stockholm, with special reference to the Ecklon and Zeyher collection. Taxon 29: 279-291.

Royen, P. van (1962) Sertulum Papuanum 5, Nymphaeaceae. Nova Guinea 8: 103-126.

Stafleu, F.A., \& Cowan, R.S. (1976) Taxonomic Literature, edn 2, vol. 1: A-G. (Bohn, Scheltema \& Holkema: Utrecht).

Verdcourt, B. (1989) Nymphaeaceae. Pp. 1-12 in R.M. Polhill, (ed.), Flora of Tropical East Africa (A.A. Balkema: Rotterdam). 